\title{
"You've Got to Be Carefully Taught": American Special Collections Library Education and the Inculcation of Exclusivity
}

ONE MIGHT WELL ASK WHAT Rodgers and Hammerstein have to do with rare books and manuscripts, or what they might have to do with special collections library education and exclusivity. This is not so easily explained, even if one happens to be familiar with "You've Got to Be Carefully Taught," the antepenultimate song from Rodgers and Hammerstein's 1949 musical South Pacific. For those who don't know South Pacific, I'm afraid space constraints do not allow for a plot summary. Suffice it to say that near the end of act two, Lieutenant Joe Cable sings "You've Got to Be Carefully Taught," a song about racial prejudice that was polemical enough in 1949 that Rodgers and Hammerstein "were counseled repeatedly ... to remove [it, because the song] was considered by many to be too controversial, too preachy, or simply inappropriate in a musical."1 The import of the short, fifteen-line number is simple: prejudice is not innate, but a learned behavior instilled in children who might otherwise remain unaffected by bias. As the final verse has it, "You've got to be taught before it's too late, / Before you are six or seven or eight, / To hate all the people your relatives hate, / You've got to be carefully taught!"

In this article, I want to ask whether we can draw a parallel between the instillation of prejudice as represented in South Pacific and the inculcation of the kind of exclusivity sometimes associated with special collections libraries and the professionals who are responsible for the materials stored there. In short, I should like to speculate briefly about whether we can say that the history of special collections library education and the current institutional opportunities for learning the skills this field demands—in essence, how we are carefully taught—are themselves implicitly responsible for the perpetuation of the elitism and restrictiveness that many people associate with our work. For my purposes, I will take special collections library education to mean those formal training opportunities that lead

1. Andrea Most, "You've Got to Be Carefully Taught: The Politics of Race in Rodgers and Hammerstein's South Pacific," Theatre Journal 52, no. 3 (2003): 309. 
to the development of what Alice Schreyer and the ARL Special Collections Task Force recently defined as core competencies, including especially "knowledge of conservation principles and techniques; general and book history and bibliography; [and an] appreciation of the role of special collections in scholarship and instruction."2 By placing special collections education against an older tradition of library training that saw libraries as democratic spaces and librarians as public servants, but also by examining MLIS curricula that outsource special collections training almost exclusively to continuing education programs, I hope to show that how we learn about special collections librarianship has the potential to elicit the very same attitudes that many practitioners now deplore.

That American special collections libraries are patrician or restrictive and the professionals who work at these places are snobbish or elitist is not of course a new idea. To many people, the special collections library is comparable to a chic, four-star restaurant, their librarians the equivalent of snooty maitre d's who delight in turning away the poorer and less fashionably dressed customers at the door. (As one friend put it when he learned about my specialization and emphasis, "Rare books librarianship? Well, la dee da!") Like most stereotypes, this one is not completely baseless, a fact that has not been lost on writers of articles about the state of the profession. Restrictive policies and the "bad" attitudes and behaviors of librarians at rare books and manuscripts repositories have been treated by a number of professionals in recent years, but perhaps most famously by Daniel Traister in his article titled "Is There a Future for Special Collections Librarianship? And Should There Be?" published in the inaugural issue of RBM in 1998. As Traister wrote, "All of us know people who have been turned away from, had difficulties at, or experienced condescension, downright rudeness, or suspicion of their integrity, cleanliness, or general demeanor while trying to use ... rare book and manuscript repositories ... Our theory too easily justifies a broad range of practices that, however well intentioned they may be, prove in execution ... to be mean-spirited, judgmental, exclusionary, hierarchical, and otiose."”

Commentators have speculated in a general way about the origins of practices that privilege preservation over access and material over users, pointing (among other things) to the often cloister-like separation of special collections from the rest of the library; the physical barriers to access at many special collections; the disproportionate monetary value of the books and manuscripts in our custody compared

2. Alice Schreyer, "Education and Training for Careers in Special Collections: A White Paper Prepared for the Association of Research Libraries Special Collections Task Force," available online at http:/ / www.arl.org/collect/spcoll/SCTF.ED.pdf (2004), 9.

3. Daniel Traister, "Is There a Future for Special Collections Librarianship? And Should There Be?" RBM 1, no. 1 (1998): 60-61. 
with general library materials; and the air of upper-class privilege associated with many of our research collections. These factors, they suggest, engender the off-putting attitudes of some professionals and foster less-than-stellar reputations among potential patrons. According to this model, special collections librarians learn to be exclusionary through immersion in an esoteric culture that continually reinforces its own "specialness," a process that Traister refers to as "absorption."

In 1985, British library educator John P. Feather observed that "the history ... of education for librarianship ... has been neglected," a statement that is less true now than it was twenty years ago. ${ }^{5}$ However, despite recent studies of special collections library education, and the increasing attention paid to "the culture of prohibition" at special collections libraries, no one has examined the role that formal instruction may have played and continues to play in the development and persistence of this culture. This is unfortunate, for although unquestionably we absorb attitudes about our work — just as we acquire skills—on the job, there also are underlying assumptions about what we do that are negotiated and transmitted in special collections courses (limited though they are in most contemporary MLIS programs).

In discussing the ideological assumptions of special collections education, it is necessary first to consider the origins of special collections as well as the earliest history of library education in America. We know that the institutionalization of library education happened more or less simultaneously with the establishment of true research libraries in American universities at the end of the nineteenth and first quarter of the twentieth centuries. The "identification and segregation" of rare books and the subsequent establishment of what we now call special collections occurred shortly thereafter. ${ }^{6}$ Significantly, as William Joyce has noted, in the earliest special collections, "there were no separate departments, no staff, and little or no money with which to make acquisitions." college research libraries as well as a multitude of newly established local public libraries relied on library education programs such as Dewey's School of Library Economy at Columbia, the library school at Pratt, the Armour Institute School in Chicago, and a handful of education programs attached to public libraries that were geared to produce professionals capable of handling cataloguing, reference, and acquisitions work. But even after separate rare book departments became more commonplace in the first quarter of the twentieth century, they tended to be

4. Ibid., 58 .

5. John P. Feather, "The Book in History and the History of the Book," in John P. Feather and David McKitterick, The History of Books and Libraries: Two Views (Washington, D.C.: Library of Congress, 1986), 14.

6. William Joyce, "The Evolution of the Concept of Special Collections in American Research Libraries," Rare Books and Manuscript Librarianship 3, no 9. 1 (1988): 27.

7. Ibid., 25 . 
staffed in a primitive manner, with "curators who often came from the faculty or the booktrade." ${ }^{8}$ Thus, if, as G. Thomas Tanselle and other writers have observed, library schools have largely "neglect[ed] ... rare-book training," this is by no means a new phenomenon. ${ }^{9}$ From the first, education for special collections librarianship was not only considered apart from the general librarianship curriculum, but all too often not considered at all.

If special collections find their origins at the end of the nineteenth century, coincident with the increasing professionalization of librarianship and the growing recognition of the need for formal library education, why were there no formal opportunities for training professionals to care for these early special collections? In part, the answer lies in the status of these earliest collections and in institutional attitudes about the material held in them. Cut off from the day-to-day business and users of research libraries, the "treasure rooms" and rare book departments appearing in colleges and public libraries around the turn of the century tended to be seen as museum-like showcases. Attitudes toward these collections had little or nothing to do with scholarly significance or potential use; rather, "their financial value-not to say prestige value or even elitism"- -was key. ${ }^{10}$ In these treasure rooms, with their few expensive items - almost exclusively rare books - there was little felt need for bibliographic organization or collection development, nor for reference or other user services. Instead, the principal duty of those who staffed these collections was the guardianship of a very physical sort of cultural capital. And formal training was hardly necessary for "gatekeepers" whose main responsibility was to keep a very narrow gate closed to the majority of library users most of the time. ${ }^{11}$

That early special collections staff should "value ... caring for, protecting, and preserving the physical objects which special collections contain" above all else, including access, should not strike us as odd; it was, in fact, an idea current for most of the last century and, one could argue, still true today. ${ }^{12}$ But there are two things worth noting about formal library education in the early days of special collections, especially in connection to my thesis about how we learn and determine our assumptions and attitudes about potential users. First, even (as we shall see) when special collections became more widespread and established, and the function of

8. Alice Schreyer, "From Treasure Room to Research Center: Special Collections in the United States," available online at http://www.initiativefortbildung.de/pdf/sondersammlungen2005/schreyer. pdf (2005), 6 .

9. G. Thomas Tanselle, "Libraries, Museums, and Reading," Raritan 12, no. 1 (1992): 77.

10. Joyce, "The Evolution of the Concept of Special Collections," 25.

11. Wayne Wiegand, "The Development of Librarianship in the United States," Libraries and Culture 24, no. 1 (1989): 101.

12. Daniel Traister, "A Caucus-Race and a Long Tale: The Profession of Rare Book Librarianship in the 1980s," Library Trends 36, no. 1 (1987): 155. 
special collections shifted, the exigencies of rare materials continued to set special collections librarians apart from other library professionals so that even when the emerging profession and new public and research libraries demanded more extensive training and formal education of its librarians, rare book and special collections staff were often exempt.

Second, as a corollary of this detail, by the time more formal educational opportunities for special collections librarians became available, a tradition of training that posited libraries (even college and research libraries) as democratic spaces, emphasizing service and instruction, had already been well established for quite some time. Indeed, since the inception of formal library education in America, this had been the predominant way librarians learned to think about their profession and the social function of their work; and this user- and access-centered emphasis is still a hallmark of American library education. It is this tradition that special collections librarians initially neglected to engage and against which professionals eventually established formal educational opportunities for those interested in special collections.

I consider this idea significant and more interesting than the materials-based preservation-versus-access binary commentators generally marshal in discussing the primary difference between nonspecial and special collections librarians (or to use Tanselle's phrase, the long-standing "split between information scientists and rare-book curators" ${ }^{\prime 3}$ ). And if I am correct in locating the origins of this sense of exclusivity or restrictedness about special collections librarianship in the history of formal library education, we must pay close attention to the assumptions and principles of the alternate tradition.

Specifically, it is not enough to say that early library programs had their students focus on intellectual content over the physicality of books. Rather, as A. Robert Rogers and Wayne Wiegand have observed, by the time formal education for librarianship had been institutionalized in the late nineteenth century, an "ideology of reading [had been] firmly cemented into the profession's subconscious." ${ }^{.14}$ Librarians at the turn of the century had established a progressive "humanistic tradition" that sought to improve and educate readers by bringing them into contact with the best that had been thought and said in the world. ${ }^{15}$ From the first, therefore, library school curricula emphasized the development of service and "skills in administration and expertise" in library management, whereas library science - to paraphrase

13. Tanselle, "Libraries, Museums, and Reading," 78.

14. Wiegand, "The Development of Librarianship in the United States,"102.

15. A. Robert Rogers, "An Introduction to Philosophies of Librarianship," in A. Robert Rogers and Kathryn McChesney, The Library in Society (Littleton, Colo.: Libraries Unlimited, 1984), 17-32. 
Dewey - included the special training needed to choose, purchase, catalog, and administer any library in the most efficient way possible for the moral and intellectual edification of patrons. ${ }^{16}$

Wiegand has discussed in several articles, and in his monographic study of Melvil Dewey, what the delegation to others outside librarianship of the responsibility for determining acquisition policies (what he calls "good reading") has meant for our profession and, specifically, the ways in which this delegation continues to limit the authority of librarians despite their professional status. ${ }^{17}$ And because the concept of authority is so often connected with exclusivity and restrictedness, if I had more space at my disposal, I would like to discuss in detail the placement of special collections education outside this dominant educational tradition and what that means to our own sense(s) of authority and power. However, for my purposes it is enough to note here that within a library education tradition whose central ideology — whatever its actual outcome — stressed egalitarianism, democracy, and service, special collections education had no place or cause. Instead, before research became a priority in special collections, and before academics and administrators came to recognize the scholarly significance of special collections holdings, if there was any ideology that informed special collections librarians' attitudes, it was to be found in the antiquarian book trade and book collecting, both of which flourished in America at the end of the nineteenth century.

I will not speculate about the extent to which this association may have influenced the more elitist members of our profession, but it is still worthwhile, if slightly obvious, to note that the constituent players in the rare books trade at its height were by and large very wealthy people whose motivations and values were not in line with the egalitarian and bureaucratic focus of early library educators. After all, as Gordon N. Ray has observed, "Before the Second World War, the collecting of rare books and manuscripts ... in the United States was to a large extent a rich man's pursuit"; though more unflatteringly, he writes that in the 1930s especially "scholars [would have been] tempted to look upon any collector of rare books as a potential 'malefactor of great wealth."'18

However, there is another reason to turn our attention to the antiquarian book trade in considering the effects of formal education on special collections librari-

16. Dewey, in Wayne Wiegand, "Perspectives on Library Education in the Context of Recently Published Literature on the History of Professions," Journal of Education for Library and Information Science 26 (1996): 276.

17. Ibid., 278-79.

18. Gordon N. Ray, "The Private Collector and the Literary Scholar," in The Private Collector and the Support of Scholarship (Los Angeles: W. A. Clark Memorial Library, 1969), 35, 51. 
anship and that is the fact that many of the core competencies ARL has identified for students interested in careers in special collections find their origins in late nineteenth- and early twentieth-century bibliophily and book collecting. It is not an exaggeration to say that during this period-what one writer has called "the age of critical bibliographic and textual studies," 19 in which the acquisition of primary source material was encouraged-booksellers, collectors, and scholars began to formally develop, and select American librarians began to learn in an informal way, the components of what we now would call special collections education, particularly as regards rare books and manuscripts. (Although early library programs, including the one at Columbia, integrated course work in bibliography, this was "bibliography" in its narrowest sense, not, as W. W. Greg has it, the study of books as tangible objects but, rather, the rote listing of works.)

The antiquarian book trade remained one of the few environments to foster core special collections skills even after these specialized collections became more widespread and established, and this remained the case even after the holdings of such collections expanded to include primary research material other than expensive rare books. In late 1955, five years after ACRL established its Rare Books and Manuscripts section, Morgan Library director Frederick P. Adams, Jr. referred to "the everywhereness of rare book rooms" and observed that although "twentyfive years ago the rare book rooms in American colleges and universities could be counted on one's fingers ... [n] ow the institution that doesn't have one tends to feel it is out of step." ${ }^{20}$ Despite this proliferation and a reimagining of special collections, not to mention the sorts of users they should serve, educational opportunities within formal programs of library education remained virtually nonexistent. Seemingly in response to Adam's query, "Where shall we look for the book-loving professionals that we need to staff our rare book rooms?" Cecil Byrd observed, in a Library Trends article written less than two years later, "some of the most successful present-day bookmen had their training in the trade. Others came to rare books directly from academic disciplines or by in-service training in rare book divisions." ${ }^{21}$ Six years later, in another Library Trends piece, Simmons professor Rollo G. Silver indicated that the situation had not changed at all: appropriate, institutional training for what he called "rare book librarians, i.e., custodians of special collections," he argued, was not being "supplied by the library schools ... [which,] harried by the great demand for librarians of all sorts, from administrators to Zatocoders, have had what seemed to be more pressing problems to consider." 22

19. Cecil K. Byrd, "Rare Books in University Libraries," Library Trends 5 (1956-1957): 441.

20. Frederick B. Adams, Jr., "Long Live the Bibliophile!" College and Research Libraries 16 (1955): 344.

21. Byrd, 449 .

22. Rollo G. Silver, "The Training of Rare Book Librarians," Library Trends 9 (1960-1961): 446. Zatocode is a system of edge-notched cards. 
Of course, as crucial as Zatocoding is to contemporary libraries, Silver might also have noted that American library schools in 1961 were- to the extent that they participated in a tradition that emphasized administration, mechanics, and bibliographic control in the service of user education and to the extent that they valued the intellectual rather than the physical aspects of books - not very different from the very first American library schools. Hence, just as at the turn of the century, and despite the changing nature and import of special collections, formal educational and training opportunities for our field remained outside the scope of the vast majority of library programs. The upshot of this exclusion from access- and user-centered curricula, even in a de facto way and beyond the obvious material differences, was the intellectual estrangement of special collections librarianship from the rest of the profession. It is not unreasonable to suggest that this situation also may have engendered the sort of exclusionary, restrictive, and elitist attitudes people still tend to associate with some special collections librarians. ${ }^{23}$

Although, as the ARL Special Collections Task Force noted in its 2004 white paper, "Education and Training for Careers in Special Collections," there are hopeful signs for students seeking opportunities to learn about and train for special collections work, the fact remains that in most mainstream library programs from midcentury until very recently, course work focused on the artifactual qualities of library holdings was almost always elective, and even then, a cursory survey suggests that opportunities to take courses in the history of the book, for example, or bibliography, or preservation, were few and far between. Today, in a digital environment in which the future of the book is debated and where the new exigencies of librarianship have persuaded some schools to go so far as to substitute the term information for library in the names of their degree programs, training for special collections has been relegated almost exclusively to continuing education opportunities.

To paraphrase Frederick Adams, it is not my purpose here to "run down" continuing education for special collections librarians; and I agree with the ARL Special Collections Task Force when, for instance, they characterize Rare Book School at the University of Virginia as an excellent and "essential resource for maintaining the high quality of their special collections personnel." ${ }^{24}$ However, in considering whether how we learn determines the nature of our attitudes about special collec-

23. Interestingly, in delineating the requirements of special collections staff, Adams, Byrd, and Silver each suggest in their way that, as Byrd puts it, professionals in our field must "possess a feeling for people" (445); and Adams evinces a particular concern for the general reputation of rare book rooms when he writes: "Having said this much about the rare book collection itself, I want to ask you to consider whether you like that name - 'rare book room.' Isn't it a rather stand-offish term? Doesn't it sound awfully precious and exclusive? I fear it has developed what the semanticists would call a pejorative connotation. And it is no longer sufficiently inclusive. Can't we think of something better, like the term 'special collections'?" (346).

24. Schreyer, "Education and Training for Careers in Special Collections: A White Paper," 12. 
tions librarianship and our potential users, it is important to give attention to this detail: formal education for special collections remains outside mainstream library programs that, in significant ways, continue to participate in the content-based, user-centered, and instructional mode inaugurated over a century ago. And it is important to ask whether this status, wherein knowledge is segregated and stratified, itself reproduces the logic of a system wherein special collections library professionals are stratified as well, not only from our nonspecial collections colleagues, but also from potential special collections users.

At the beginning of this article I suggested that the subject of restrictive policies and the bad attitudes of librarians at rare books and manuscripts repositories has been treated most famously by Daniel Traister in "Is There a Future for Special Collections Librarianship? And Should There Be?" When Traister published this article in 1998 , the notion of abandoning the idea of "special users for special collections" was still radical enough that he subtitled his piece "a polemical essay." Today, in contrast, several professional organizations such as RBMS have encouraged the utilization of special collections in new ways by nontraditional users, and many practitioners have followed their lead. Central to such proposals is the assumption that by increasing the visibility of, and accessibility to, this material, we run counter to a culture of elitism and restrictedness that characterized our profession for most of the last century.

It has been my purpose to neither criticize this trend nor question the effectiveness of changing attitudes about and within special collections; indeed, I will not offer alternatives to this situation and I hesitate to suggest that the status is worth changing. However, to the extent that we do strive to change our colleagues', our users', and our own perceptions about special collections, I think we need to consider each possible source of such exclusivity. And as I hope to have shown that the ways we learn about special collections librarianship have maintained and continue to perpetuate the sense of superior difference that many practitioners now seek to abolish, this will necessarily include a more weighty consideration of how we are taught—and how carefully.

\section{WANTED AUTOMOBILE LITERATURE 1900-1915}

I buy sales brochures, repair \& owner's manuals, books, showroom items, artwork, models \& toys, posters or any items pertaining to automobiles, trucks or motorcycles... I travel to purchase collections.

Walter Miller 6710 Brooklawn Pkwy. Syracuse, NY 13211 USA $315-432-8282$ fax 315-432-8256 e-mail: info@autolit.com

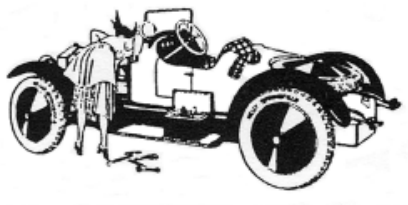

